\title{
FINAL WASH PRECIPITATE FEED SIMULANTS FOR DWPF COLD CHEMICAL RUNS (U)
}

by J.C. Marek

Westinghouse Savannah River Company

Savannah River Site

WSRC-RP-92-703

Aiken, South Carolina 29808

DE93 003706

This paper was prepared in connection with work done under Contract No. DE-AC09-89SR18035 with the U. S. Department of Energy. By acceptance of this paper, the publisher and/or recipient acknowledges the U.S. Government's right to retain a nonexclusive, royalty-free license in and to any copyright covering this paper, along with the right to reproduce and to authorize others to reproduce all or part of the copyrighted paper. 


\section{DISCLAIMER}

This report was prepared as an account of work sponsored by an agency of the United States Government. Neither the United States Government nor any agency thereof, nor any of their employees, makes any warranty, express or implied, or assumes any legal liability or responsibility for the accuracy, completeness, or usefulness of any information, apparatus, product, or process disclosed, or represents that its use would not infringe privately owned rights. Reference herein to any specific commercial product, process, or service by trade name, trademark, manufacturer, or otherwise does not necessarily constitute or imply its endorsement, recommendation, or favoring by the United States Government or any agency thereof. The views and opinions of authors expressed herein do not necessarily state or reflect those of the United States Government or any agency thereof.

This report has been reproduced directly from the best available copy.

Available to DOE and DOE contractors from the Office of Scientific and Technical Information, P.O. Box 62, Oak Ridge, TN 37831; prices available from (615) 576-8401, FTS 626-8401.

Available to the public from the National Technical Information Service, U.S. Department of Commerce, 5285 Port Royal Rd., Springfield, VA 22161. 


\section{Keywords: DINPE Cold Chemical Runs, DWPE, Precipitate Hydrolysis process, salt process cell}

Retention Period: Permanent

CC: M. J. Plodinec, 773-A

C. T. Randall, 704-T

J. T. Carter, 704-1T

S. R. Young, 704-1T

PTD Group (8)

\section{$M E M \Omega B A N Q U M$}

To: E. W. Holtzscheiter, 773-A

From: J. C. Marek, 704-T \& CMarek

$$
\begin{aligned}
& \text { FINAL WASH PRECIPITATE FEED } \\
& \text { STMUIANTS EOR DKPF COLD CHMMICAL BUNS }
\end{aligned}
$$

\section{SUMMARY}

Precipitate feed simulant specifications for Defense waste processing Facility (DWPF) Cold Chemical Runs are revised in this report. All previous specifications of precipitate feed simulants for DWPF Cold Chemical Runs (CCRs) $1-7$ are superceded by this document. The revision is needed to 1) eliminate use of hydroxylamine nitrate (HAN) in the precipitate process operation, 2) simulate the projected composition of the precipitate feed to DWPE produced by final washing to reduce the nitrite concentration to $\leq 0.01 \mathrm{M}$ without washing the simulated feed, 3) delete organic trim chemical additions to the precipitate feed and 4) specify an additive to prevent foaming of the precipitate. Two specifications are provided to operate the salt Processing Cell (SDC) with mercury (Tests $5 \& 6$ ) and without mercury (Tests $1-4$ ) in the precipitate feed.

\section{INTRODUCTION}

The Defense waste Processing Facility (DWPE) is scheduled to start non-radioactive process operation in September, 1992. The Cold Chemical Runs will demonstrate acceptable process operation and provide data required to satisfy the waste compliance Plan 8 . Five basic sludge simulants will be required for these tests ${ }^{9}$. Two basic precipitate simulants will be needed to operate the SPC with and without mercury in the precipitate feed.

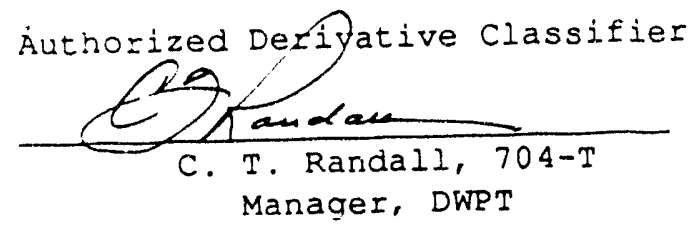




\section{DISCUSSION}

\section{Calculatienal Bases}

The calculational bases for the DWPF CCR precipitate feed specifications were derived from WSRC-TR-92-211, Rev. 010. This material balance for the In-Tank Precipitation and DWPF flowsheet incorporates late (or final) washing to reduce the nitrite content of the precipitate feed stored in Tank 49 to $\leq 0.01 \mathrm{M}$ prior to transfer to the DWPF Sait process Cell. The precipitate feed, sludge feed, and resulting glass component flows were calculated using the above bases and current tank farm blending schedules, assuming the ni.rite concentration in Tank 49 is $0.08 \mathrm{M}$ and the final washing reduces th: nitrite content to $0.01 \mathrm{M}$. The integrated processing computer model developed using CPES software was used for the calculations.

\section{Variability of Precipitate Feed to UWRE}

The precipitate feed to DWPE will have little compositional variability until the existing waste inventory has been processedll. This is because the In-Tank Process (washing the precipitate slurry and filtering to a constant 10 wto insoluble solids in Tank 48) and the final washing to $\leq 0.01 \mathrm{M}$ nitrite remove most of the soluble salts, which tend to vary the most in concentration from waste tank to waste tank. The nitrite concentration in Tank 49 during radioactive operation is projected to exceed the $0.08 \mathrm{M}$ calculational basis assumed in WSRC-TR-92-211. The nitrite concentration will likely be about $0.17 \mathrm{M}$, but the late washing operation will remove only an additional 6\% of the soluble species from the precipitate feed. The greatest variability will likely occur for the minor soluble anions and insoluble siudge components present because sludge is entrained to varying degrees in the salt waste. Glass composition will be kept relatively constant by the appropriate blending of precipitate and sludge feeds.

\section{Simulated Precipitate slurry Preparation}

Preparation of the simulated precipitate feed is outined in Figure 1. A reliable method to prepare the precipitate simulant is to combine $a$ vendor supplied solution of potassium salts with a vendor supplied sodium tetraphenylborate (NaTPB) solution. Specifications and compositions of the required salt and NaTPB solutions are shown in Tables 1-3. The NaTPB solution is nearly identical in composition to that specified for the In-Tank (Precipitation) Process (ITP), with two minor changes. First, for water balancing between the salt and NaTPB solutions the NaTPB is at a slightly lower concentration of $0.5 \mathrm{M}$ $\pm 0.05 \mathrm{M}$ rather than $0.55 \mathrm{M} \pm 0.05 \mathrm{M}$ specified for ITP. Second, the maximum allowable halide content has been reduced to $100 \mathrm{ppm}$ in the NaTPB solution used in preparing the feed simulants.

Surfactant (antifoam) additions to the salt solution before precipitation are recommended to disperse the precipitate solids (which greatly enhances the ability to quantitatively transfer the slurry) and prevent foaming and subsequent segregation of solids from the supernate. The recommended surfactant is $2,4,7,9$-tetramethyl5-decyn-4,7-diol. Tests to determine the minimum effective surfactant 
concentration are in progress but for procurement purposes it can be assumed that a maximum of 0.3 wto of the active ingredient is required in the precipitate slurry. The surfactant is a white, waxy solid material but is available in liquid form from Air Products Co. under the trade name Surfynol(B) 104E, as a 50/50 weight mixture of the surfactant in ethylene glycol solvent. Surfynol® 104E has been tested in the SRTC laboratories and PHEF at TNX with positive results and must be added at 0.6 wto to obtain 0.3 wto active surfactant.

The order of addition of the various reagents to the feed preparation tank is 1) the potassium salt solution, 2) the sodium titanate, 3) the surfactant solution followed by 4) the NaTPB solution to form the white tetraphenylborate precipitate. To generate diphenylmercury in Tests $5 \& 6$, the formation of the precipitate is followed by addition of an aqueous mercuric nitrate solution to form diphenylmercury. The tank should be agitated during all additions.

Specifications and compositions of the required trim chemicals are shown in Tables 1-2. Organic trim chemicals that were recommended in previous specifications have been deleted from this specification for the following reasons:

1) The latest analytical results for irracliated feeds indicate lower values for organic high-boilers than had been found previously. These data were part of the late washing technical assessment.

2) Addition of the organic trim chemicals requires additions of benzene in gross excess of the material balance projections.

3) Information to be obtained in cold Chemical Runs on decanter and stripping performance will not be sacrificed because other organics (e.g. diphenylamine) can be monitored.

4) It is not possible to add these materials in the same state they are present in irradiated precipitates - in irradiated precipitates they are present within the solid potassium tetraphenylborate crystal.

5) The addition of the organics has at least once caused a severe operating difficulty in PHEF operations 12 that could potentially hinder achieving the objectives and schedule for cold chemical runs. It was related to item 4) above and not to any phenomena anticipated for radioactive feeds.

\section{Simulated Precipitate compesition}

Compositions of the simulated precipitate feeds for DWPF CCRs are shown in Tables 4-5. The simulants have nitrite concentrations of $0.01 \mathrm{M}$ and differ only in mercury content. The alkali content is maintained constant for all the feeds by including the appropriate amount of potassium nitrate where necessary.

All the primary inorganic cations present at greater than 0.1 wt: in the design basis material balancelo were retained in the washed precipitate feed simulant. Some compounds present at less than C.I wto were retained because they are important for glass product 
composition. These include sodium metaborate, silicate, chromate, and molybdate. Other minor compounds were retained because they react in precipitate hydrolysis or are key corrosion species, including sodium carbonate and sulfate. Ammonium ion was deleted from the specification because 1) it generates toxic ammonia fumes when present in alkaline media and 2) ammonia scrubbers will not be installed in the CPC before the start of CCRs. Anions such as aluminate were omitted because including them in the precipitate feed would have little or no effect on glass composition or the precipitate process.

Insoluble sodium titanate was included in the precipitate feed simulant because it is important for demonstration of glass quality and process control. Sludge solids were deleted from the precipitate specification because the actual quantity of sludge solids entrained in the salt waste is highly variable, the sludge has no impact on the CCR objectives, and the sludge would contribute excessive nitrite.

There is still considerable activity within the Interim waste Technology Division regarding sodium titanate requirements for the ITP. The amount of sodium titanate specified here is near the upper level that is currently anaticipated for most real feeds to DWPE 13 . The sodium titanate material procured for addition to SRP waste tanks in the ITP is unacceptable for preparing simulants for DWPF Integrated

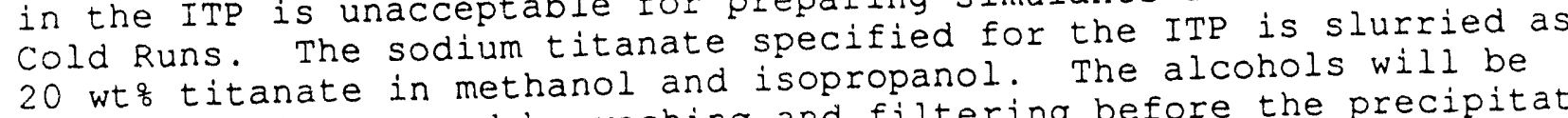
substantially removed by washing and filtering before the precipitate is fed to DWPF. The sodium titanate solution desired for the precipitate simulant should have a total alcohol. content equivalent to or less than that shown for isopropanol in Tables 1 and 2 . The alcohol content of the sodium titanate can be reduced by the vendors by either batch washing and decantation or by distillation. The sodium titanate solution should not contain ethanol or other two-carbon solvents for reasons relating to process safety.

\section{Simulant Compared to Expected Radieactive Feeds}

The washed precipitate feed simulant includes potassium at the reference CPES calculated level (molar basis). The precipitate simulant will have considerable excess sodium and nitrate in relation to the CPES material balance with final washing. The excess sodium and nitrate are the result of the simplified precipitation method used to prepare the feed without a subsequent washing operation. The excess sodium in the precipitate simulant has been corrected for by removing the appropriate amount of sodium hydroxide from the sludge simulant specification. This will provide the proper feed specification to the glass melter. An alternative to prepare precipitate simulant with the reference sodium and ritrate levels would be to wash the feed in the pump pits. This alternative was rejected because it would require the addition of washing facilities and the objectives of the CCRs can be met with the specified precipitate simulant.

\section{Quantities ef Materials}

Table 6 shows the quantities of feed and product simulants that will be required for each DWPF Integrated cold Run. These quantities were 
calculated using blending rates for the PHA and glasslit and the appropriate melter turnover volumes 15 . Over 1.1 million pounds of precipitate slurry will be needed for the six tests.

\section{Allowable Yariance in compenent concentrations}

The task team responsible for developing specifications for all feed materials has recoumended maximum allowable variances for the simulant specifications ${ }^{9}$. The allowable variances are summarized in table 7. The specification for nitrite in the precipitate slurry simulant is $\pm 10 \%$ to control the nitrite concentration at the late washing target of $0.01 \mathrm{M}$. The specifications for the total halide (chloride plus fluoride) content of the salt solution (20 ppm) and the NaTPB solution $(100 \mathrm{ppm})$ as well as the allowable variance on sulfate ( $\pm 10 \%$ ) are important for corrosion control purposes. Other components present at levels of greater than 1.5 wto (dry basis) can vary $\pm 10 \%$. Components present in the precipitate simulant at less than 1.5 wto but greater than 0.01 wto (dry basis) can vary $\pm 25 \%$, and components specified in the precipitate simulant at less than 0.01 wt $f$ (dry basis) can vary $\pm 75 \frac{2}{\circ}$. The latter specification is based on analytical sensitivity limitations. Iron and aluminum impurities should be less than $200 \mathrm{ppm}$ (dry basis). Because the precipitate simulant is prepared by the combination of two solutions, the total quantity of salt solution and NaTPB solution combined to produce the feed should be controlled to within $\pm 2.5 \%$ of the amounts shown in Tables $1 \& 2$ to obtain an acceptable variance in the component concentrations.

\section{QUAIITY ASSURANCE}

A computer model was developed by the author to calculate the compositions and quantities of chemicals required to prepare the precipitate slurry simulant and the precipitate hydrolysis aqueous

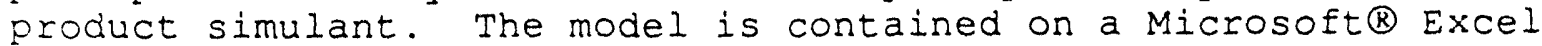
spreadsheet that runs on an Apple $\mathbb{B}$ Macintosh ${ }^{\mathrm{TM}}$ personal computer. The computer model contains internal checks for errors by mass balance calculations. The same model has been used successfully to calculate precipitate feed simulants for research and development work in the Precipitate Hydrolysis Experimental Facility at TNX.

Calculations were verified by the author and by the leader of the SRTC Cold Feed Task Team. Verification included comparison of hand calculations to output of the computer model and a check of each calculational cell formula. A copy of the hand calculations and spreadsheet formulas have been added to the task team leader's file of pertinent DWPF Cold Feed Run documents. These documents will be placed in a permanent $Q A$ file upon completion of all task team feed specification work. A copy of each set of calculations has been placed on floppy disks that will stored permanently in the DWPE Cold Feed Run QA file.

\section{REFERENCES}

1. J. C. Marek, DPST-88-417, DWPE Integrated Cold Runs Feed Specifications Precipitate Slurry Feed compesition and Preparation, August 17, 1988. 
2. J. C. Marek, DPST-88-417 Rev. 1, DWPE Integrated Cold Buns Eeed Specifications precipitate slurry Feed compesition and Rreparation, May 22, 1989.

3. J. C. Marek, WSRC-RP-90-350, Revised Comeesition and preparation Specifications for Precipitate slurry Feed simulants, March 29, 1990.

4. J. R. Knight, WSRC-RP-90-1057, Becommended Bevisions te Eeed Simulant specifications for DWPE Integrated Cold Buns, September 10, 1990.

5. J. C. Marek, WSRC-RP-90-350, Rev. 1, Bevised Compesition and Preparation Specifications for Precipitate Slurry Feed Simulants, September 26, 1990.

6. L. F. Landon, WSRC-RP-89-238, Rev. 1, Revised Feed Simulant Specifications for Integrated cold Runs in the Defense Waste Recessing Eacility, November 30, 1990.

7. J. C. Marek, WSRC-RP-91-1176, Salt Solution for Zere Nitrite Precipitate Eeed Simulants, November 22, 1991.

8. J. A Gentilucci, PL No. 0000099 , Specification Requirements synthetic and special cold Feeds for Integrated cold Run eperations, October 14, 1987.

9. J.R. Fowler et. al. to J. R. Knight, WSRC-RP-89-238, Development ef Feed Simulant Specifications for Integrated cold Runs ic the Defense Waste Processing Facility, July 28, 1989.

10. A. S. Choi, WSRC-TR-92-211, Preliminary Material Balance Tables for the DWPE Einal Wash Elowsheet, April 30, 1992.

11. J. R. Fowler, DPST-87-713, Prejected Compesitions of SRP Waste Glass for the Waste Acceptance Preliminary Specifications, March 22, 1988.

12. J. C. Marek, SRL-PTD-91-0106, Precessing the Clunkers in PHEP PHT Eeed Material, September 30, 1991.

13. D. D. Walker, IWT-LWP-90-0088, Minutes of Meeting en Sodium Titanate usage Requirements, March 6, 1990.

14. J. T. Carter, DPST-88-395, DWPE Integrated Celd Runs Feed specifications sludge Compesitions, March 9, 1988.

15. J. B. Mellen to J. R. Knight, OPS-DTA-890003, Eeed Simulant Specifications for Integrated cold Runs in the Defense waste Precessing Eacility, october 30, 1989. 
FIGURE 1

\section{PREPARATION OF PRECIPITATE SIMULANT}

1) SALT SOLUTION
2) NaTi2O5H SLURRY

3) SURFACTANT

4) NaTPB SOLUTION

5) $\mathrm{Hg}(\mathrm{NO}) 2$ SOLUTION

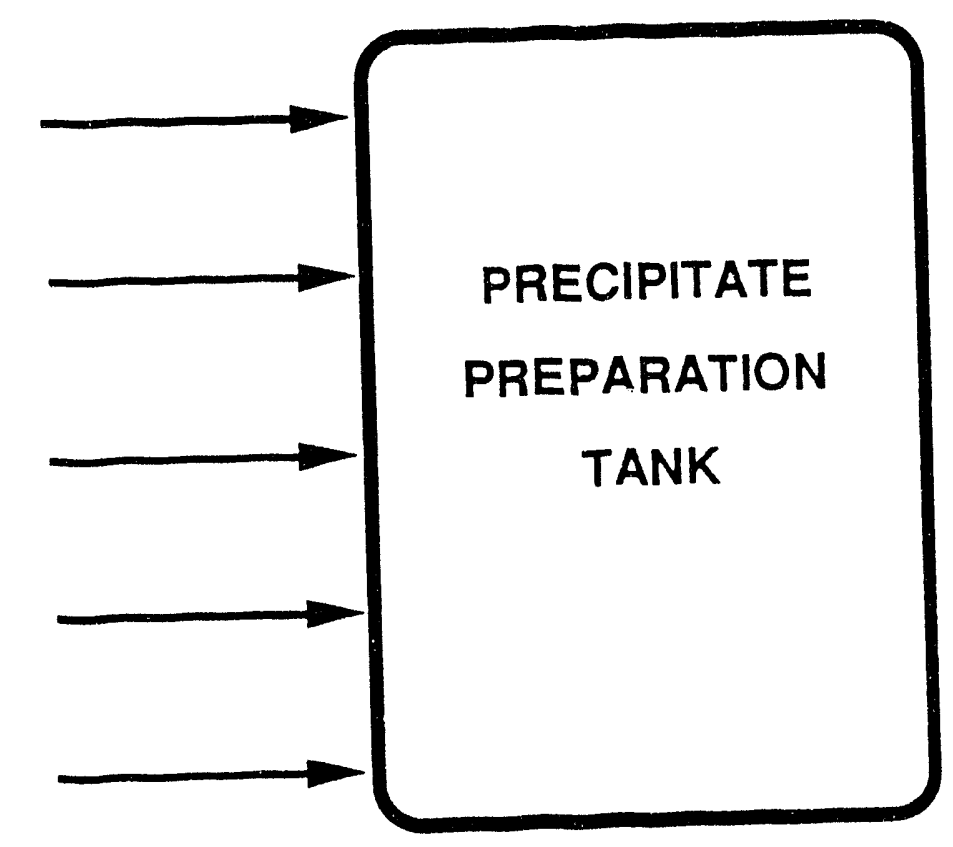


TABLE 1. REAGENTS FOR PRECIPITATE WITH NO MERCURY

\section{SAIT SOTUITON}

\section{COMPCUND}

$\mathrm{H} 2 \mathrm{O}$

$\mathrm{KNO} 3$

$\mathrm{K} 2 \mathrm{CO} 3$

$\mathrm{KNO} 2$

$\mathrm{CsNO} 3$

$\mathrm{C} 6 \mathrm{H} 5 \mathrm{OH}$

$\mathrm{K} 2 \mathrm{C} 2 \mathrm{O} 4$

$\mathrm{B}(\mathrm{OH}) 3$

$\mathrm{K} 2 \mathrm{SO} 4$

$\mathrm{K} 3 \mathrm{PO} 4$

$\mathrm{K} 2 \mathrm{CrO} 4$

$\mathrm{K} 2 \mathrm{SiO} 3$

$\mathrm{K} 2 \mathrm{MOO} 4$

TOTAL

\section{B / 1000 IAB SIURRY}

437.32

19.53

1.73

0.76

0.52

0.45

0.29

0.20

0.043

0.0033

0.001

0.0009

0.00016

460.85
WI8 WET BASIS

94.89

4.24

0.375

0.165

0.11

0.098

0.063

0.043

0.009

0.0007

0.0002

0.0002

0.000035

100
WTE DRY BASIS

0

83.0

7.34

3.24

2.23

1.92

1.24

0.83

0.18

0.140 .014

$0.004 \mathrm{fcm}$

0.0007

100

SORIUM TITANATE SIURRY

COMPOUNID

$\mathrm{NaTi} 205 \mathrm{H}$

(CH3) $2 \mathrm{CHOH}$

$\mathrm{H} 2 \mathrm{O}$

TOTAL

\section{IR/1000 IB SIURRY}

1.85

0.0001

7.4

9.25
HTR FET BASIS

19.9992

0.0008

80.0
WW' DRY BASIS

99.996

0.004

0.0

100

SURFACTANT: 2,4,7,9-tetramethyl-5-decyn-4,7-diol, 50 wt: in ethylene glycol. Quantity to be specified.

SODIUM TETRAPHENYIBORATE (NATPB) SOLUTION

COMPOUND

$\mathrm{H} 2 \mathrm{O}$

$\mathrm{NaTPB}$

$\mathrm{NaOH}$

TOTAL
IB/1000 IB SLURRY

437.29

90.67

1.93

529.89
WTT WET BASIS

$$
\begin{array}{r}
82.52 \\
17.11 \\
0.37
\end{array}
$$

100
WIS DRY BASIS

0

97.9

2.1

100 
E. W. Holtzscheiter

TABLE 2. REAGENTS FOR PRECIPITATE WITH MERCURY

SAIT SOIUTION

COMPOUNR

$\mathrm{H} 2 \mathrm{O}$

$\mathrm{KNO} 3$

$\mathrm{K} 2 \mathrm{CO} 3$

KNO2

$\mathrm{CsNO} 3$

$\mathrm{C} 6 \mathrm{H} 5 \mathrm{OH}$

$\mathrm{K} 2 \mathrm{C} 2 \mathrm{O} 4$

$\mathrm{B}(\mathrm{OH}) 3$

$\mathrm{K} 2 \mathrm{SO} 4$

$\mathrm{K} 3 \mathrm{PO} 4$

$\mathrm{K} 2 \mathrm{CrO} 4$

$\mathrm{K} 2 \mathrm{SiO} 3$

$\mathrm{K} 2 \mathrm{MOO} 4$

TOTAL
IB/1000 IB SIURRY

417.33

19.53

1.73

0.76

0.52

0.45

0.29

0.05

0.043

0.0033

0.001

0.0009

0.00016

440.72
WT2 WET BASIS

94.69

4.43

0.39

0.17

0.12

0.10

0.066

0.011

0.010

0.00075

0.0002

0.0002

0.000036

100

KU? WTET BASIS

$$
\begin{gathered}
19.9992 \\
0.0008 \\
80.0
\end{gathered}
$$

1.85

7.4

100

WEF DRY BASIS

0

83.5

7.39

3.26

2. 24

1.94

1. 25

0.21

0.18

0.014

0.004

0.004

0.0007

TOTAL

IB/1000 IB SIURRY

$\mathrm{NaTi} 2 \mathrm{O} 5 \mathrm{H}$
$(\mathrm{CH} 3) 2 \mathrm{CHOH}$

$\mathrm{H} 2 \mathrm{O}$ $2,4,7,9$-tetramethyl-5-decyn-4,7-diol, 50 wt: in
ethylene glycol. Quantity to be specified.
99.996
0.004
0.0

WTE DRY BASIS 
TABLE 3: Anion, Cation, Organic and Elomental content of salt and sodium Tetrapheny lborate solutions

\section{Salt selution}

specie

$K^{+}$

$\mathrm{NO}_{3}^{-}$

$\mathrm{CO}_{3}{ }^{2-}$

$\mathrm{C} 6 \mathrm{H} 5 \mathrm{OH}$

$\mathrm{NO}_{2}^{-}$

$\mathrm{Cs}^{+}$

$\mathrm{B}(\mathrm{OH}) 3$

$\mathrm{C}_{2} \mathrm{O}_{4}{ }^{2-}$

B

$\mathrm{SO}_{4} 2-$

$\mathrm{PO}_{4}^{3-}$

$\mathrm{CrO}_{4}^{2-}$

$\mathrm{SiO}_{3}{ }^{2-}$

Cr

Si

$\mathrm{MOO}_{4}{ }^{2-}$

Mo

NaTPB Selution

specie

$\mathrm{Na}^{+}$

$\mathrm{OH}^{-}$

$\mathrm{TPB}^{-}$

NTE DRY BASIS

Tests 1-4

38.4

51.6

3.2

1.92

1.75

1.52

0.83

0.66

0.15

0.10

0.0062

0.0025

0.0020

0.0011

0.00074

0.00045

0.00027

\section{Tests 586}

38.65

51.9

3.2

1.34

1.76

1.53

0.21

0.66

0.037

0.10

0.0063

0.0026

0.0019

0.0012

0.00070

0.00046

0.00028
Wto DRY BASIS (aI1 tests)

\section{A11 Tests}

7.77

0.885

91.35 
TABISE 4. COMPOSITION OF PRECIPITATE SIMTITANT FOR TESTS 1-4

CONPOUND
K2O
KTPB
NaNO3
NaTPB
CsTPB
NaOH
NaTi2O5H
Na2CO3
NaNO2
CEH $50 H$
Na2C2O4
Na2B 407
Na2SO4
Na3PO4
Na2CrO4
Na2SiO3
Na2MOO4

WTH BATS BAS

88.2

8.28

1.66

0.97

0.243

0.186

0.185

0.13

0.062

0.045

0.024

0.016

0.0035

0.00025

0.00003

0.00007

0.00001

\section{HTE DBY BASIS}

0

70.1

14.1

8.21

2.06

1.58

1.57

1.12

0.52

0.38

0.20

0.135

0.03

0.0022

0.0007

0.0006

0.0001 
$\begin{array}{llr}\text { E. W. Holtzscheiter } & -12- & \text { WSRC-RP-92-703 } \\ \text { May 15, } 1992\end{array}$

TABLE 5. COMPCSITION OF PRECIPITATE SIMUTANT FOR TESTS 586

COMPOUNID

$\mathrm{H} 2 \mathrm{O}$

KTPB

NaNO3

NaTPB

CSTPB

NaTi205H

$\mathrm{Hg}(\mathrm{C} 6 \mathrm{H} 5) 2$

$\mathrm{NaOH}$

$\mathrm{Na} 2 \mathrm{CO} 3$

$\mathrm{NaNO} 2$

$\mathrm{C} 6 \mathrm{H} 5 \mathrm{OH}$

$\mathrm{Na} 2 \mathrm{C} 204$

$\mathrm{Na} 2 \mathrm{~B} 407$

$\mathrm{Na} 2 \mathrm{SO}_{4}$

$\mathrm{Na} 3 \mathrm{PO}_{4}$

$\mathrm{Na} 2 \mathrm{CrO} 4$

$\mathrm{Na} 2 \mathrm{SiO} 3$

$\mathrm{Na} 2 \mathrm{MOO} 4$
WT? FET BASIS

88.0

8.28

1.75

0.97

0.243

0.185

0.168

0.16

0.132

0.062

0.045

0.024

0.016

0.0035

0.00025

0.00008

0.00007

0.00001
QT: DRY BASIS

0

68.8

14.5

8.06

2.02

.54

1.4

1.33

1.10

0.51

0.38

0.20

0.133

0.03

0.002

0.0007

0.0006

0.0001 
$\begin{array}{llr}\text { E. W. Holtzscheiter } & -13- & \text { WSRC-RP-92-703 } \\ \text { May 15, } 1992\end{array}$

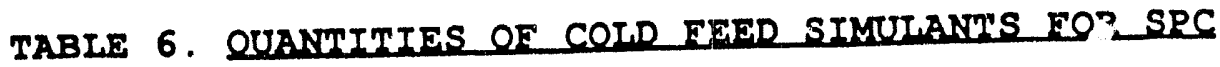

CAMPAIGN

Test 1

Blended Sludge

Test 2

Blend $w / N d$ Tracer

Test 3

Low Viscosity,

Purex

Test 4

High Viscosity,

HM

Test 5

Batch 1 with $\mathrm{Hg}$

Test 6

Batch 1/spike

Total
IBS PBFCTPITATE SIMUTHANT

$$
\text { Minimum* }
$$

281,050

234,310

126,930

139,620

133,940

147,340

208,280

229,110

208,280

229,110

$1,312,080$

* Represents value required for the Cold Chemical Runs with no allowance for excess quantities, rounded up to nearest 10 lbs. 
TABIE 7. ALTOFARIE VARIANCES IN PRECIPITATE EEED SIMULANTS

\section{GENERAL VARIANCES}

COMPONERT

$\mathrm{NO} 2-, \mathrm{SO} 4=$

Other Components > 1.5 wt: (dry basis)

Other Components < 1.5 wt: but

$>0.01$ wto (dry basis)

Other Components $<0.01$ wto (dry basis)

Fe, Al (dry basis)

Maximum variation in batch size

quantities of potassium salt

solution and NaTPB solution

Halides (Chloride, Fluoride)

- Salt Solution

- NaTPB Solution

\section{NATPB SOLUTION}

COMPONIENT

Sodium Tetraphenylboron, NaTPB

Sodium Hydroxide, $\mathrm{NaOH}$

Benzene

Halides (CI, F)

Copper

$\mathrm{pH}$
ALIOWABIE VARIANCE

$\pm 10 \frac{9}{6}$

$\pm 10 \%$

$\pm 25 \%$

$\pm 75 \%$

200 ppm max.

$\pm 2.5 \frac{8}{8}$

$20 \mathrm{ppm} \max$

$100 \mathrm{ppm} \max$.

\section{ALIOHABIE VARIANCE}

$\pm 0.05 \mathrm{M}$

$\pm 0.025 \mathrm{M}$

$<650 \mathrm{ppm}$

$<100 \mathrm{ppm}$

$<5 \mathrm{ppm}$

$12.5 \pm 1.5$ 


\section{TABLE 7, cont'd. ALTOKABLIE VABIANCES}

IN PRECIPITATE FFED SIMUTANTSS

\section{ROTASSIUM SAIT SOLUTION}

\section{COMPONENT}

$\mathrm{NO} 2-, \mathrm{SO} 4=$

Other Components > 1.5 wt: (dry basis)

Other Components < 1.5 wto but

$>0.01$ wt: (ary basis)

B, Cr, Mo, Si

Benzene

Halides (Cl, E)

Copper

$\mathrm{Fe}, \mathrm{Al}$

Total Insoluble Solids

$\mathrm{pH}$

\section{JITOWABIE VARIANCE}

$\pm 10 \%$

$\pm 10 \%$

$\pm 25 \%$

$\pm 75 \%$

$<650 \mathrm{ppm}$

$<20$ ppm

$<10 \mathrm{ppm}$

$<200 \mathrm{ppm}$

$<2.0$ wt\% wet basis

$8-12$

\section{SODIURA TITANATE SIURRY}

\section{COMPONENT}

Monosodium Titanate, NaTi205H

Total Alcohol Content

$\mathrm{NaOH}$

Total Soluble

Inorganic Salts

Total Halide (Cl, F)

Total Carbon

Particle size distribution

Percent smaller than 1 micron

percent larger than 35.5 microns

\section{ATIOFABLE VARIANCE}

$200 \pm 20 \mathrm{~g} / \mathrm{I}$

$\leq 0.0008$ wt $\frac{2}{0}$

$0.10 \pm 0.02 \mathrm{M}$

$<20 \mathrm{~g} / \mathrm{I}$

$<300 \mathrm{ppm}$

$<100 \mathrm{ppm}$

$<1 \%$

$<1 \%$ 

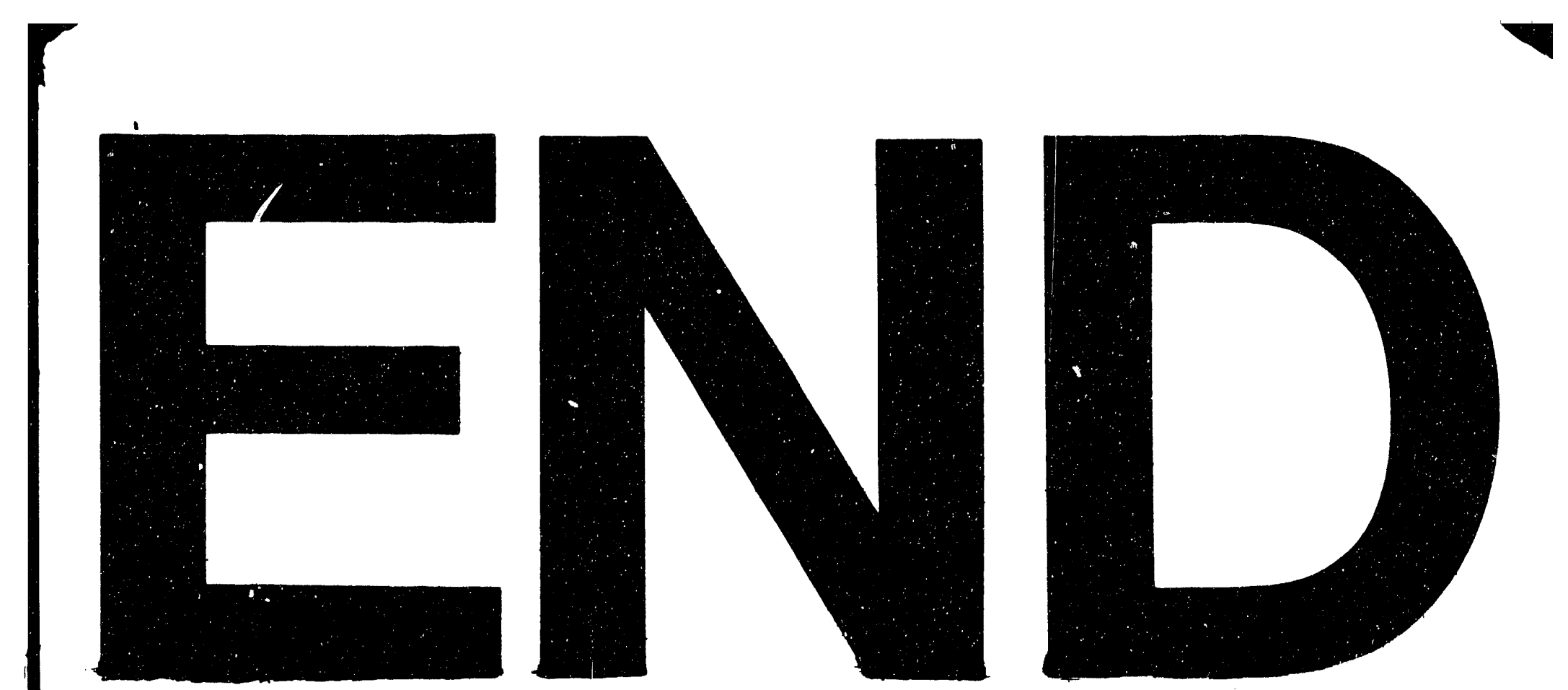

is - inglow
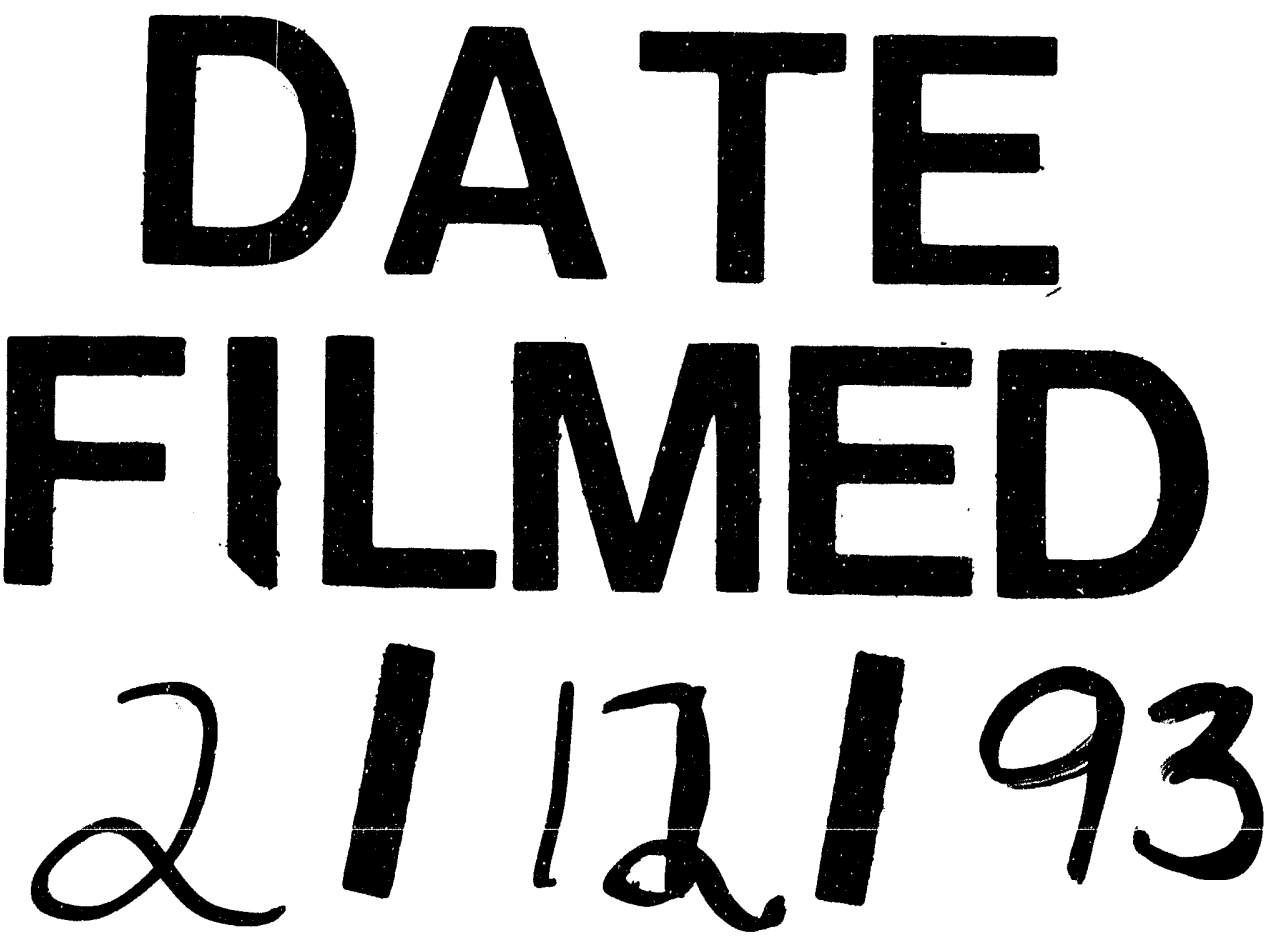


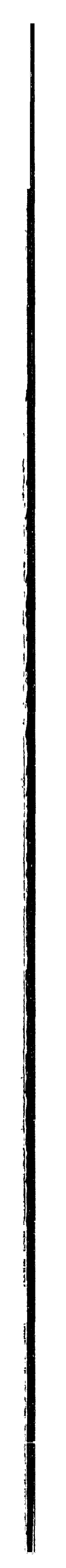

